\title{
HIV Reverse Transcriptase Inhibitors of Natural Origin
}

\author{
Gesa Matthée ${ }^{1}$, Anthony D. Wright ${ }^{1}$, and Gabriele M. König ${ }^{2 *}$ \\ 1 Institute for Pharmaceutical Biology, Technical University of Braunschweig, Braunschweig, Germany \\ 2 Institute for Pharmaceutical Biology, University of Bonn, Germany
}

Received: October 13, 1998; Accepted: January 24, 1999

\begin{abstract}
Inhibitors of HIV reverse transcriptase (RT) are important drugs for the treatment of acquired immuno-deficiency syndrome (AIDS). One approach to identify novel inhibitors of HIV-1-RT is the screening of natural compounds. Many natural products have been shown to be active as RT inhibitors. These compounds belong to a wide range of different structural classes, e.g., coumarins, flavonoids, tannins, alkaloids, lignans, terpenes, naphtho- and anthraquinones, and polysaccharides. The life forms from which the bioactive compounds were isolated are as equally diverse and comprise terrestrial and marine plants, micro-organisms, and marine animals. From the most extensive screening effort, carried out by the $\mathrm{NCl}$, calanolide $\mathrm{A}$, isolated from the terrestrial plant Calophyllum lanigerum (Guttiferae), has been discovered as the most interesting natural RT inhibitor. The promise of this natural product probably relates to a novel mechanism of action. The current review describes natural products from various sources that are able to inhibit HIV-RT.
\end{abstract}

Key words: HIV-1-reverse transcriptase, inhibition, natural products, plants, micro-organisms, marine organisms.

\section{Introduction}

Acquired immuno-deficiency syndrome (AIDS) and the causative retrovirus, human immuno-deficiency virus (HIV), have been extensively studied, and several specific processes in the viral life cycle identified that can serve as drug targets (1). One critical and at the same time unique step in the replication of retroviruses is the reverse transcription of genetic material, which is catalysed by the enzyme reverse transcriptase (RT). Currently, AIDS therapy relies on a triple combination of HIV-1-RT and HIV-protease inhibitors $(2,3)$. The high mutation rate of HIV frequently results in the rapid development of resistance towards the employed drugs (4). For this reason there is a continuous need for alternative inhibitors of HIV related enzymes, including HIV-RT. Newly identified RT inhibitors, with novel structural features and different mechanisms of inhibiting the enzyme will help to delay the development of resistance, and thus to control HIV infection. New chemical entities with such activities may be

Planta Medica 65 (1999) $493-506$

(C) Georg Thieme Verlag Stuttgart · New York identified through a variety of approaches, one of them being screening of natural products.

Recently, Vlietnick et al. (5), Ng et al. (6), and Kinghorn (7) reviewed plant-derived anti-HIV compounds. The current review focuses on a specific molecular target of HIV, that is RT, and describes natural products from various sources that are able to inhibit this enzyme. Compounds are grouped according to their source organism, i.e., plant, micro-organism, and marine organism. This grouping serves to underline the fact that natural products with HIV-RT inhibitory activity are widely distributed in nature.

\section{Reverse Transcriptase}

RT was discovered in 1970 when DNA-dependent RNA-synthesis in RNA tumour viruses was being investigated $(8,9)$. In principle, RT is a DNA polymerase that synthesizes doublestranded DNA using a single-stranded RNA as template. For this purpose the multifunctional enzyme possesses RNAdirected DNA polymerase (RDDP), ribonuclease $H$ (RNase $H$ ), and DNA-directed DNA polymerase (DDDP) activities (10). In the early 1970s DNA polymerases were studied since retroviruses were known to be implicated in the development of malignant diseases such as leukemia and solid tumours. When it was discovered that AIDS was caused by a retrovirus (11), research on RT of HIV became a focus (12). Antimoniotungstate (HPA23) was the first clinically effective HIV-RT inhibitor (13). Subsequently, the RT-inhibitor 3'-azido-3'deoxythymidine (AZT) (14), originally described in 1974 as being active against murine retroviruses (15), was approved as anti-HIV drug.

The biochemistry and molecular biology of HIV-RT has been extensively studied. During the biosynthesis of RT in HIV-1 (16) the primarily translated protein is cleaved resulting in the production of a dimeric enzyme precursor composed of two $66 \mathrm{kDa}$ subunits (p66/p66). This premature enzyme is subsequently processed by HIV-1-protease to give the active heterodimeric p66/p51 HIV-1-RT. For structure determinations, as well as for characterisation of enzymatic activities it was crucial to have purified homogeneous p66/p51 HIV-1-RT. To date various expression schemes and purification protocols have been described for the production of recombinant HIV1-RT. Most commonly, Escherichia coli is used for overexpression of the subunits of HIV-1-RT $(17,18,19)$, followed by 
chromatographic purification of the stable dimer (19). X-ray analysis of HIV-1-RT, crystallised with nevirapine (20), and double-stranded DNA (21), showed clearly the asymmetric structure, in which the p66 subunit possesses the active polymerase and RNase $\mathrm{H}$ subdomains.

The successful production of HIV-1-RT through recombinant techniques has made the identification of inhibitors a reasonably straightforward process. The specificity of inhibitors can be determined by measuring their inhibitory properties towards other purified polymerases (e.g., 22, 23). The activity of RT may be measured by quantifying one of the multiple functions of the enzyme, i.e., RDDP, DDDP or RNase $\mathrm{H}$ activity $(24,25)$. The majority of assays used for determining enzyme activity measure the incorporation of labeled nucleotides into newly synthesised DNA, thus quantifying the polymerase activity (26). In principle, isotopic (27) and non-isotopic (28) detection of the enzyme activity is possible. Isotopic assays measure the amount of radioactive ${ }^{3} \mathrm{H}$ - or $\alpha_{-}{ }^{32} \mathrm{P}$-labeled DNA synthesised by RT, after a separation step on DE81 filters or after gel electrophoresis (e.g., 29, 30). To date, most studies on HIV-1-RT inhibitors have been done employing isotopic assays which allow, to some extent, results from different laboratories to be compared. Non-isotopic assays, on the other hand, which can be performed without any loss of sensitivity and specificity, have advantages regarding safety and handling. For the latter assay nucleotide-triphosphates labeled with digoxigenin or biotin are commercially available, and allow the activity of HIV-RT to be determined using nonradioactive ELISA based technologies $(31,32,33)$.

\section{HIV Reverse Transcriptase Inhibitors of Clinical Importance}

Nucleoside RT inhibitors (NRTI) were the first anti-HIV agents broadly employed clinically. Their efficacy as anti-retrovirals is well established, and despite the development of resistance, they are still the most important class of anti-AIDS drugs. Interestingly, the isolation of arabinofuranosylthymine and arabinofuranosyluracil, from a Caribbean sponge, Cryptotheca crypta (34), led to the eventual investigation of the antiviral effects of nucleosides (35). Currently, five NRTIs have been approved by the U.S. Food and Drug Administration (US FDA), i.e., 3TC (Lamivudin ${ }^{\circledR}$ ), Zalcitabine (HIVID ${ }^{\circledR}$ ), Zidovudin or AZT (Retrovir $\left.{ }^{\circledR}\right)$, ddI $\left(\right.$ Videx $\left.^{\circledR}\right)$, and d4T (Zerit ${ }^{\circledR}$ ). NRTIs are prodrugs, they are triphosphorylated by kinases and then function as competitive inhibitors and chain terminators (36). The first non-nucleosidic RT inhibitor (NNRTI), nevirapine, was identified from a library of muscarinic receptor antagonists (37). Two NNRTIs have been approved by the FDA, nevirapine (Viramune ${ }^{\circledR}$ ), and delvaridine (Rescriptor ${ }^{\circledR}$ ). Another promising NNRTI is the natural product calanolide A (1), a coumarin NNRTI isolated from the antiviral extract of Calophyllum lanigerum (Guttiferae), and currently under investigation in a clinical phase I study $(38,39)$. Kinetic studies have shown that the approved NNRTIs do not interact with RT competitively (40). Crystallographic investigations of the HIV-1-RT nevirapine complex showed that the drug binds to the enzyme at a different site to that of the template-primer and the nucleotides, providing evidence of a noncompetitive interaction and a steric influence of NNRTIs on HIV-RT (20). Recently, several novel mechanisms of RT inhibition have been described revealing oligonucleotides, ribozymes, RNase $\mathrm{H}$ and dimerisation inhibitors to serve as possible anti-HIV-1-RT agents (41).
As newly identified NNRTIs may interact with the enzyme in as yet undiscovered ways, screening approaches to find new lead structures are considered very promising.

\section{Reverse Transcriptase Inhibitors from Plants}

Probably the most extensive screening effort undertaken for anti-HIV drugs from natural sources has been done by the US National Cancer Institute ( $\mathrm{NCI})$. So far, the most promising compounds coming from this endeavour were obtained from extracts of the fruits and twigs of Calophyllum lanigerum. Of eight coumarins isolated, calanolides A (1) and B (2) were found to be the most active in the cell-based anti-HIV-1 assay, when compared with the other analogues. Calanolide A (1) fully protected human T-lymphoblastic cells from the cytopathogenic effects of HIV-1 at concentrations where no apparent cytotoxic effects were observed. Calanolide A (1) and calanolide $\mathrm{B}(\mathbf{2})$ act as non-nucleoside HIV-1-RT inhibitors. The $\mathrm{IC}_{50}$ of $0.07 \mu \mathrm{M}$ for calanolide A (1), when tested against HIV-1-RT using a ribosomal RNA template, and its selective inhibition of only HIV-1-RT, and not HIV-2-RT illustrate the compound's special features and potential usefulness as a drug. This is supported by the fact that $\mathbf{1}$ is active against resistant strains of HIV (AZT-resistant strain G-9106, and pyridone-resistant strain A17). In this respect 1 differs markedly from other NNRTIs, suggesting that it indeed represents a new class of NNRTIs (39). Related coumarin secondary metabolites, this time isolated from Calophyllum inophyllum, have also been investigated. The inophyllums (e.g., 3) are closely related structurally to the calanolides, with the only difference being the presene of a phenyl ring instead of a propyl side chain at C-4. Inophyllum B (3) is comparable to calanolide A (1) with respect to its RT-inhibitory potency ( IC $_{50} 0.04 \mu \mathrm{M}$ ), but it has lower selectivity, when protection of cultured cells from viral infection and cytotoxicity are compared (42). When the potential of calanolide A and related compounds was realised, a sustainable natural source for such chemicals was sought, as the original source is rare. In order to provide basic chemotaxonomic data, the NCI lately has analysed its repository specimens and extracts of the genus Calophyllum for the content of pyranocoumarins and for their anti-HIV activity (43). In an earlier study it was found that the latex of Calophyllum teysmannii var. inophylloide contained the RTinhibitors costatolide [(-)-calanolide B] (44) and soulattrolide (45), a C-10, C-11 stereoisomer of inophyllum B (3). These compounds, even though of lower potency, seem to be possible alternatives to calanolide $A$, since the latex which contains them can be harvested repeatedly. The latex, however, has only traces of calanolide $A(\mathbf{1})(<0.1 \%)$, so a sustainable resource for this compound is as yet unknown. During these studies it also became obvious that only one enantiomer each of $\mathbf{1}$ and $\mathbf{2}$, that is $(+)$-calanolide $A$ and $(-)$ calanolide B, respectively, were biologically most active (46). Recently, cordatolides, compounds that are similar to the calanolides (1, 2) and inophyllum B (3) have been isolated from C.cordato-oblongum, with the only difference being a methyl residue at $\mathrm{C}-4$, but with a significantly lowered RT inhibitory activity (47). Another way to provide sufficient amounts of these substances for drug development is total synthesis, which was reported for racemic and more recently also for $(+)$-calanolide A $(\mathbf{1})(48,49)$. In this specific case synthesis is even more important since, as Flavin et al. report, the original source of $(+)$-calanolide was destroyed and other 
members of the same species, occurring in the vicinity were found to be devoid of $\mathbf{1}$ (50). The reported synthesis provided adequate amounts of substance in good yields, and allowed structure-activity correlations for calanolide A (1) and a number of its derivatives to be made. These studies indicated the trans orientation of the C-10 and C- 11 methyl groups, and the $12 \beta-\mathrm{OH}$ of the saturated $\mathrm{A}$ ring to be of considerable importance for activity. The natural compound (+)-calanolide A (1) possesses superior activity when compared to the synthetic analogues and the racemate. Even though the (+)enantiomer of $\mathbf{1}$ is the active agent, the racemic mixture is currently undergoing phase I clinical trials $(50,39)$.

Ancistrocladus korupensis (Ancistrocladaceae), a newly identified and extremely rare tropical rain forest plant of Cameroon, yielded the novel dimeric naphthoquinones michellamines A$C$, three atropisomers which were shown to protect human lymphoblastoid cells from HIV-1 and HIV-2. Michellamine B (4), the most potent and abundant of the three isomers is currently undergoing preclinical development (51). Detailed investigation of the mechanism of HIV-inhibition showed that michellamine B inhibited cellular fusion, syncytium formation, and additionally HIV-RTs. Enzymatic assays showed michellamine B to inhibit drug-sensitive and drug-resistant HIV-1-RT and HIV-2-RT, most probably by a mechanism distinct from that of other RT inhibitors. The michellamines thus represent yet another class of natural products most suitable for drug development (52).

Several synthetic and naturally occurring naphtho- and anthraquinones were investigated for their activity towards cultured HIV, and specifically towards isolated RTs. Two of these compounds, $\mathbf{5}$ and $\mathbf{6}$, were found to inhibit HIV-1-RT selectively since the activity of DNA polymerase $\alpha$ was hardly influenced. The activity of one of them, hypericin $\left(\mathrm{IC}_{50}=0.77 \mu \mathrm{M}\right)(\mathbf{5})$, was shown, however, to depend on the absence of bovine serum albumine (BSA) $(53,54)$. In tissue cultures and animal models an anti-HIV activity was detected for hypericin; several phase I clinical dose escalation trials were initiated. Photoactivation seems to be essential for its activity, but is also a dose limiting factor due to severe phototoxicity $(55,56)$. Studies on the mechanism of action of hypericin (5) revealed that its virucidal effect is not due to HIV-1-RT inhibition but mainly caused by affecting the budding of the virus $(57,58)$. Currently, an oral formulation of hypericin is being investigated in a further clinical trial (59). The second compound, 1,2,5,8-tetrahydroxyanthraquinone $\left(\mathrm{IC}_{50}=3.1 \mu \mathrm{M}\right)(\mathbf{6})$, was found to be cytotoxic at $87.8 \mu \mathrm{M}$, and therefore unsuitable as drug candidate (53).

The acetogenin protolichesterinic acid (7), from the lichen Cetraria islandica (Glaciomyceae) was shown to inhibit HIV-1RT. This substance was moderately active $\left(\mathrm{IC}_{50}=24 \mu \mathrm{M}\right)$, but not of further interest since the activity relates to nonspecific binding to the enzyme (60).

Other secondary metabolites from higher plants with RT inhibitory activity include tannins, flavonoids, and alkaloids $(61,62,63,64)$. In many investigations RTs other than of HIV were used for prescreening, assuming that the polymerase or substrate binding sites were similar in RTs of different origin (e.g., 65). The results obtained using this approach must be viewed critically, however, and are thus only discussed marginally in this report.

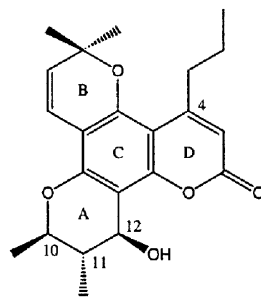

(+)-Calanolide A (1)<smiles>CC1Oc2c3c(c4oc(=O)cc(-c5ccccc5)c4c2O1)C=CC(C)(C)O3</smiles>

Inophyllum B (3)<smiles></smiles>

Hypericin (5)<smiles>CCCc1cc(=O)oc2c3c(c4c(c12)OC(C)(C)C=C4)O[C@H](C)[C@@H](C)[C@H]3O</smiles>

(+)-Calanolide B (2)

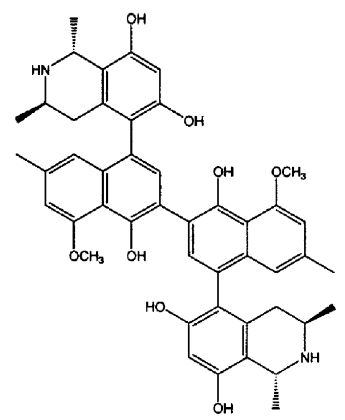

Michellamine B (4)<smiles>O=C1c2ccc(O)c(O)c2C(=O)c2c(O)ccc(O)c21</smiles>

1,2,5,8-Tetrahydroxyanthraquinone (6)<smiles>O=C(O)c1cc(O)c(O)c(O)c1</smiles>

Gallic acid (8)

Tannins have been known as RT inhibitors for nearly 15 years when hydrolysable; also condensed tannins from different medicinal plants were shown to inhibit avian myeloblastosis virus (AMV) RT (61). Ellagitannins, such as oenothein B were found to inhibit the replication of HIV in vitro, an activity which may partly be due to RT inhibition (66). A comparative study of gallic (8) and digallic acid (9), and semisynthetic derivatives thereof demonstrated that only those structures based on 9 inhibited murine leukemia virus (MLV), as well as HIV-RT. Digallic acid (9) itself causes $90 \%$ inhibition of HIV-1RT at a concentration of $0.5 \mu \mathrm{g} / \mathrm{ml}$ (67). HIV-1-RT was also inhibited by tetragalloylquinic acids (10), albeit at high concentrations i.e., 80 to $90 \%$ inhibition at $100 \mu \mathrm{M}$. The antiHIV activity of $\mathbf{1 0}$ was confirmed in a cell-based assay with HIV/H9 lymphocytes. Even though other DNA polymerases are also strongly inhibited by compound 10, the overall cytotoxicity of the compound was judged as marginal by the authors (68). In a recent report the hydrolysable tannins shephagenins A and B $(\mathbf{1 1}, \mathbf{1 2})$, from Shepherdia argentea 
(Eleagnaceae), exhibited remarkable activities as HIV-1-RT inhibitors with $\mathrm{IC}_{50}$ values of 49 and $74 \mathrm{nM}$, respectively (69). Two other tannin-type compounds having interesting levels of activity and unusual structural features are also worth mentioning here. One of them, compound 13, was found when 41 traditional Egyptian herbal drugs were screened with HIV-1-RT as the target enzyme. Subsequently, extracts from the fruit of Phyllanthus emblica (Euphorbiaceae) were found to be active and investigated in detail after a nonspecific interaction with protein (BSA) was excluded. The somewhat unusual tannin-like compound putranjivain A (13) was eventually isolated from $P$. emblica as the active principle, and displayed potent HIV-1-RT inhibition $\left(\mathrm{IC}_{50}=3.9 \mu \mathrm{M}\right)(70)$. The structurally related compound repandusinic acid A (14), originally identified from Mallotus repandus (Euphorbiaceae) (71), was obtained from P.niruri. It also exhibited strong inhibitory activity towards HIV-1-RT $\left(\right.$ IC $\left._{50}=0.05 \mu \mathrm{M}\right)$, with DNA polymerase $\left(\mathrm{IC}_{50}=0.6 \mu \mathrm{M}\right)$ being influenced to a much lower degree, indicating $\mathbf{1 4}$ to have some, albeit weak, selectively. Repandusinic acid A is an effective inhibitor of HIV-1 cytopathogenity, but also shows some cytotoxicity (22).

Despite the fact that some tannins exhibit significant HIV-RT inhibition in vitro, as exemplified by the gallotannins punica-<smiles>O=C(O)c1cc(O)c(O)c(OC(=O)c2cc(O)c(O)c(O)c2)c1</smiles>

Digallic acid (9)

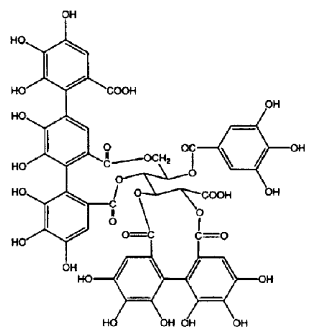

Shephagenin A (11)

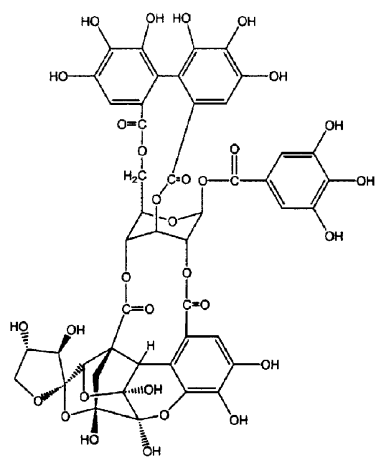

Putranjivain A (13)

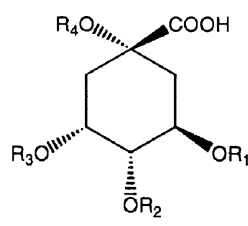

$R_{1}-R_{4}$ : -galloyl or $-\mathrm{H}$

Tetragalloylquinic acids (10)

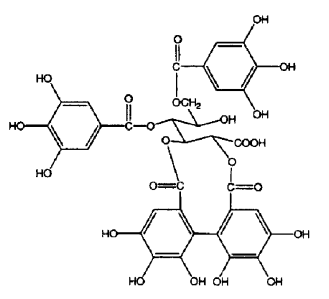

Shephagenin B (12)

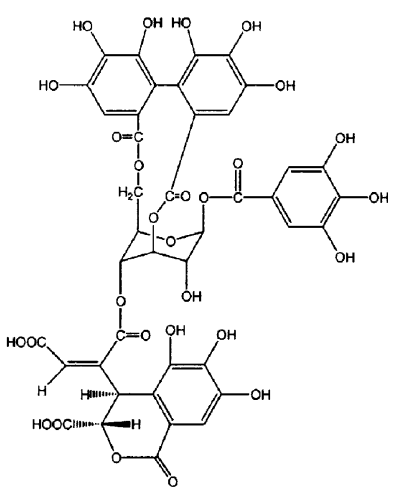

Repandusinic acid A (14) lin and punicacortein $\mathrm{C}\left(\mathrm{IC}_{50}=8\right.$ and $5 \mu \mathrm{M}$, respectively) (60), their antiviral activity as observed in cell-based assays is more likely to be due to interference with virus-cell adhesion (72). This mechanism of action was confirmed in a comprehensive study on HIV and RT inhibition involving 42 different tannins. This investigation showed that HIV-1-RT inhibitory activity of tannins could not be correlated with their anti-HIV activity in cell culture assays, and only slight HIV inhibition was observed in the absence of toxicity. Therefore, it was concluded that the relevance of tannins as anti-HIV drugs is limited due to their toxicity (73). Furthermore, epicatechin 3gallate (15), a potent inhibitor of HIV-1-RT and other polymerases in vitro, was shown to be active only if BSA was absent in the reaction mixture (23). The HIV-1-RT inhibitory activity of other catechins and the related flavonols quercetin (16) and myricetin (17) was also shown to be dependent on the absence of BSA, also suggesting a non-specific mechanism of action for these compounds (23). Overall, various types of tannins and related phenolic compounds have been extensively studied as possible lead structures for HIV-RT inhibitors. The activities found, however, suggest that pursuit of common tannins as HIV RT inhibitors is no longer worthwhile.

The antiviral activity of various flavonoids against several viruses in cell cultures, and in animal models, has been demonstrated (74). Preliminary screening of 18 flavonoids towards various RTs resulted in the detection of three with weak inhibitory activity (approx. 50-70 $\mu \mathrm{M}$ ) towards AMVRT: quercetin (16), amentoflavone (18), and scutellarein (19) (53). In a further study, using Rauscher murine leukemia virus (RLV) RT and HIV-1-RT, several flavonoids, namely quercetin (16), myricetin (17), baicalein (20) and quercetagenin (21) were found to almost completely inhibit both enzymes at concentrations of $1 \mu \mathrm{g} / \mathrm{mL}$ and $2 \mu \mathrm{g} / \mathrm{mL}$, respectively. Detailed analysis of the activity of these compounds revealed that only baicalein (20) was a selective RT inhibitor, since the other compounds also inhibited further DNA polymerases (54). Similar results were obtained in a study that investigated the effect of 190 flavonoids on AMV-RT (64). The assessment of 16, 17, 20 and 21 in a cell-based assay (HIV-1/MT-4 cells) demonstrated that all compounds were cytotoxic at concentrations which did not significantly inhibit HIV-1-RT (63). Due to the sheer amount of data relating to RT inhibition of flavonoid compounds, structure-activity relationships (SAR) have been performed $(5,54,55)$. Whether such studies are of any relevance, since RTs of different origin were used, and especially regarding the possible in vivo activity of flavonoids, is questionable. An unusual and novel type of flavononexanthone glycoside, swertifrancheside (22), was isolated from Swertia franchetiana (Gentianaceae) (75). Swertifrancheside was identified as a HIV-1-RT inhibitor with only weak activity $\left(\mathrm{IC}_{50}=43 \mu \mathrm{M}\right)$. The mode of action was found to be related to the binding of swertifrancheside to DNA, and may explain why it is also an inhibitor of several other polymerases, including DNA polymerase, and thus not a selective HIV-1-RT inhibitor (60). Several cytotoxic phloroglucinol derivatives were isolated from Mallotus japonicus (Euphorbiaceae) (76, 77); later some of them were found to be inhibitors of HIV-1RT. Mallotojaponin (23) and mallotochromene (24) inhibited the enzyme at a concentration of $10 \mu \mathrm{g} / \mathrm{ml}(23 \mu \mathrm{M})$ to around $70 \%$. Kinetic analysis revealed that the mechanism of the inhibition is similar to that of flavonoids, e.g., baicalein (20) (78). Unfortunately, at this point it has to be concluded that 
common flavonoids identified as RT inhibitors are likely to be of no further interest for the development of leads as HIV-1RT inhibitors.<smiles>O=C(c1ccc(O)c(O)c1)[C@]1(C(=O)c2cc(O)c(O)c(O)c2)Cc2c(O)cc(O)cc2O[C@H]1c1ccccc1</smiles>

Epicatechin 3-gallate (15)<smiles>O=c1c(O)c(-c2cc(O)c(O)c(O)c2)oc2cc(O)cc(O)c12</smiles>

Myricetin (17)<smiles>O=c1cc(-c2ccc(O)c(O)c2)oc2c(O)c(O)c(O)c(O)c12</smiles>

Scutellarein (19)<smiles>O=c1c(O)c(-c2ccc(O)c(O)c2)oc2cc(O)c(O)c(O)c12</smiles>

Quercetangenin (21)<smiles>O=c1c(O)c(-c2ccc(O)c(O)c2)oc2cc(O)cc(O)c12</smiles>

Quercetin (16)<smiles>O=c1cc(-c2ccc(O)cc2)oc2c(-c3cc(-c4cc(=O)c5c(O)cc(O)cc5o4)ccc3O)c(O)ccc12</smiles>

Amentoflavone (18)<smiles>O=c1cc(-c2ccccc2)oc2cc(O)c(O)c(O)c12</smiles>

Baicalein (20)<smiles>COc1cc(O)c2c(=O)c3c(O)c(-c4c(O)c(C5OC(CO)CCC5O)c(O)c5c(=O)cc(-c6ccc(O)c(O)c6)oc45)cc(O)c3oc2c1</smiles>

Swertifrancheside (22)
Benzophenanthridine alkaloids such as fagaronine (25) and nitidine (26) $(79,80)$, and protoberberine alkaloids such as berberine (27), and palmatine (28) (81), have long been known as inhibitors of RTs of AMV, RLV and simian sarcoma virus. Years later, in an effort to find HIV-1- and HIV-2-RT inhibitory compounds Tan et al. screened 156 natural products, many of them alkaloids, for such properties (82). While protoberberine alkaloids, e.g., berberine chloride $(27)\left(\mathrm{IC}_{50}=\right.$ $60.9 \mu \mathrm{g} / \mathrm{ml}, \mathrm{HIV}-1-\mathrm{RT}, \mathrm{IC}_{50}=57.8 \mu \mathrm{g} / \mathrm{ml}$, HIV-2-RT) had only weak activity, the benzophenanthridine-type alkaloids fagaronine chloride (25) and nitidine chloride (26) were found to inhibit HIV-1- and HIV-2-RT more strongly and with similar potency $\left(\mathrm{IC}_{50}\right.$ values $\approx 10 \mu \mathrm{g} / \mathrm{ml}$ ). The moderate HIV-1-RT inhibitor $O$-methylpsychotrine sulfate heptahydrate $(\mathbf{2 9})\left(\mathrm{IC}_{50}\right.$
$=21.8 \mu \mathrm{g} / \mathrm{ml})$, and psychotrine dihydrogen oxalate $(\mathbf{3 0})\left(\mathrm{IC}_{50}=\right.$ $18.3 \mu \mathrm{g} / \mathrm{ml}$ ), isolated from Cephaelis ipecacuanha (Rubiaceae), were shown to be about four times more active towards HIV2-RT. A key structural element for the activity of 0 -methylpsychotrine sulfate heptahydrate (29) and psychotrine dihydrogen oxalate (30) seems to be the imine functionality. It was also observed that these isoquinoline alkaloids were only active when applied as the exact salts (83). Other ipecac alkaloids (emetine hydrochloride, cephaeline hydrochloride, and psychotrine as free base), as well as other groups of alkaloids that were tested, e.g., quinolizidines, pyrrolizidines, and indolizidines were found to be inactive (84). The extract of flowers, leaves, and twigs of Euodia roxburghiana (Rutaceae), a tree used in folk medicine in Australia and regions of Asia, showed anti-HIV activity in the NCI screen. This activity was traced to the quinoline alkaloids buchapine (31) and $\mathbf{3 2}$. Both compounds act as HIV-1-RT ihibitors $\left(\mathrm{IC}_{50}=12\right.$ and $8 \mu \mathrm{M}$, respectively), and are additionally active in cell based anti-HIV testing. Further investigation of quinolone type compounds may thus be warranted (85).

Lignans are a further group of natural products with antiviral activity, as described several years ago studying murine cytomegalovirus (MCV) inhibitors (86), and as recently reviewed (87). Well known lignans with anti-HIV activity (H9 cells infected with HIV-1) are (-)-arctigenin (33) and (-)trachelogenin (34), isolated from Ipomoea cairica (Convulvolaceae) (88). In vitro studies showed that the activity of (-)arctigenin (33) and (-)-trachelogenin (34) was primarily caused by inhibition of HIV proviral DNA integration into cellular DNA, and not related to interference with HIV-1-RT (89). When tested towards isolated HIV-integrase, compounds which were suggested to be metabolites of $\mathbf{3 3}$ and 34, but not the lignans themselves, strongly inhibited HIV-integrase (90). Inhibition of RT, however, was found to be the mode of action of (-)-gomisin J (35) ( IC $_{50}=45 \mu \mathrm{g} / \mathrm{ml}$, HIV-1-RT), a dibenzocyclooctadiene-type lignan identified as the active principle in fruits of Schisandra chinensis (Schisandraceae). In an attempt to optimise the biological activity of gomisin $\mathrm{J}$ various halogenated derivatives were prepared, with one of them, a dibrominated derivative, compound 1506 (36) being more potent $\left(\mathrm{IC}_{50}=1 \mu \mathrm{g} / \mathrm{ml}, \mathrm{HIV}-1-\mathrm{RT}\right)$ and selective than the natural product (91).

A further group of HIV-1-RT inhibitors identified in Schisandra sp. extracts were lignans based on the tetrahydronaphthalene skeleton. In an attempt to reduce their cytotoxicity a series of derivatives was prepared and subjected to a detailed study of their antiviral properties. In the course of this investigation the synthetic lignan compound 1737 (37) proved to be the most active $\left(\mathrm{IC}_{50}=3.6 \mu \mathrm{M}\right.$, HIV-1-RT, $\mathrm{ED}_{50}=0.8 \mu \mathrm{M}, \mathrm{HIV}-1 /$ MT-4 cells, selectivity index 71.9) and compound 1738 (38) the most selective compound $\left(\mathrm{IC}_{50}=1.7 \mu \mathrm{M}, \mathrm{HIV}-1-\mathrm{RT}, \mathrm{ED}_{50}=\right.$ $3.3 \mu \mathrm{M}$, HIV-1/MT-4 cells, selectivity index > 253). The antiviral action of these substances is clearly caused by their action on RT (92). A further tetrahydronaphthalene lignan (39), isolated from Haplophyllum ptilostylum (Rutaceae) demonstrated only moderate HIV-1-RT inhibition $\left(\mathrm{IC}_{50}=33 \mu \mathrm{M}\right)$, when compared to $\mathbf{3 7}$ and $\mathbf{3 8}$ (93).

The triterpenoid, salaspermic acid (40) was isolated by following the anti-HIV activity of a methanolic extract from roots of the liana Tripterygium wilfordii (Celastraceae), a plant 
<smiles>COc1c(C)c(O)c(C(C)=O)c(O)c1Cc1c(O)c(CC=C(C)C)c(O)c(C(C)=O)c1O</smiles>

Mallotojaponin (23)<smiles>COc1cc2c[n+](C)c3c4cc5c(cc4ccc3c2cc1OC)OCO5</smiles>

Nitidine chloride (26)<smiles>CC[C]1CN2CCc3cc(OC)c(OC)cc3[C@@H]2C[C@@]1(C)CC1=NCCc2cc(O)c(OC)cc21</smiles>

O-Methylpsychotrine sulfate heptahydrate (29)<smiles>COc1c(C)c(O)c(C(C)=O)c(O)c1Cc1c(O)c2c(c(C(C)=O)c1O)OC(C)(C)C=C2</smiles>

Mallotochromene (24)<smiles>COc1ccc2cc3c(cc2c1OC)[N+]1=CC=C(CC1)c1cc2c(cc1-2)OCO3</smiles>

Berberine chloride (27)<smiles>CC[C@]1(C)CN2CCc3cc(OC)c(OC)cc3[C@@]2(C)C[C@@]1(C)CC1=NCCc2cc(O)c(OC)cc21</smiles>

Psychotrine dihydrogen oxalate (30)<smiles></smiles>

Fagaronine chloride (25)<smiles></smiles>

Palmatine (28)<smiles>C=CC(C)(C)C1(CC=C(C)C)C(=O)Nc2ccccc2C1=O</smiles>

Buchapine (31)<smiles>CC(C)=CCOC1c2ccccc2NC(=O)C1CC=C(C)C</smiles>

Quinoline compound (32)

found in Southern China where it is used as a traditional remedy. Compound $\mathbf{4 0}$ was shown to inhibit HIV replication in $\mathrm{H} 9$ lymphocytes at a non-toxic concentration $\left(\mathrm{EC}_{50}=\right.$ $10 \mu \mathrm{M})$. RT inhibition by salaspermic acid (40) is, however, weak $\left(\mathrm{IC}_{50}=32 \mu \mathrm{M}\right)$, and selectivity only moderate as DNA polymerase was inhibited at a five-fold higher concentration. The RT inhibitory properties of several closely related analogous from the same plant were compared with those of 40; none proved to be more potent. It thus seems that the acetal and carboxyl moiety in $\mathbf{4 0}$ are essential for activity (94). The pentacyclic triterpenoid, $1 \beta$-hydroxyaleuritolic acid 3-p-hydroxybenzoate (41) was isolated together with other terpenoid esters from Maprounea africana (Euphorbiaceae). Compound $41\left(\mathrm{IC}_{50}=3.7 \mu \mathrm{M}\right)$ and related compounds are quite potent HIV-1-RT inhibitors, but kinetic analysis seems to suggest an unspecific mode of action, and therefore further analysis of these compounds was not considered useful (95, 96). Another HIV-RT inhibiting triterpene, the secocycloartene derivative nigranoic acid (42), was isolated from the Chinese medicinal plant Schisandra sphaerandra (Schisandraceae). Nigranoic acid inhibited the DDDP and RDDP activity of HIV1 -RT ( IC $_{50}$ values 40 and $158 \mu \mathrm{M}$, respectively), but also other RTs and polymerases, thus, 42 represented a relatively unspecific and only moderately active inhibitor (97). Euphorbia myrsinites (Euphorbiaceae) yielded a number of diterpe- noid esters, of which two, 43 and 44, inhibited HIV-1-RT with very weak activity, displaying $\mathrm{IC}_{50}$ values of 125 and $103 \mu \mathrm{M}$, respectively (98).

\section{Reverse Transcriptase Inhibitors from Micro-Organisms}

Screening of microbial extracts for HIV-1-RT inhibitors and subsequent isolation of the active principles has resulted in the identification of several promising leads. A nocardioform actinomyceta (exact taxonomy undetermined) isolated from the bark of the Alaskan Betula papyrifera (Betulaceae), was found to produce the novel chromodepsipeptides, quinoxapeptins $A$ and $B$ (45 and 46). Quinoxapeptin A is the more active of the two metabolites, displaying an $\mathrm{IC}_{50}$ towards HIV1-RT and HIV-2-RT of 4 and $40 \mathrm{nM}$, respectively. It also appears to be a selective inhibitor of HIV-1-RT and HIV-2-RT, since it does not affect the activity of human DNA $\alpha, \beta, \gamma$, and $\delta$ polymerases at analogous concentrations. The same authors who reported on the quinoxapeptins investigated the structurally closely related antibiotic luzopeptin A, a compound with the same peptide backbone but different heterocyclic chromophores (99), and originally isolated from the actinomycete Actinomadura luzonensis (100). This compound displayed comparable potency towards HIV-1-RT and HIV-2-RT $\left(\mathrm{IC}_{50}=7\right.$ and $\left.68 \mathrm{nM}\right)$ to those reported for the quinoxapeptins. 
<smiles>COc1cc(C[C@H]2C(=O)OC[C@H]2Cc2ccc(OC)c(OC)c2)ccc1O</smiles>

(-)-Arctigenin (33)<smiles>COc1c(O)cc2c(c1OC)-c1c(cc(O)c(OC)c1OC)C[C@H](C)[C@@H](C)C2</smiles>

Gomisin J (35)<smiles>COc1cc([C@@]2(C)c3c(cc(OC)c(O)c3OC)C[C@H]3CSC[C@@H]32)cc(OC)c1O</smiles><smiles>COc1cc(C[C@]2(O)C(=O)OC[C@H]2Cc2ccc(OC)c(OC)c2)ccc1O</smiles>

(-)-Trachelogenin (34)<smiles>COc1c2c(c(OC)c(OC)c1OC)-c1c(c(Br)c(O)c(O)c1OC)C[C@H](C)[C@H](C)C2</smiles>

Compound 1506 (36)<smiles>COc1cc([C@]2(C)c3c(cc4c(c3OC)OCO4)C[C@H]3CSC[C@@H]32)ccc1OCc1ccccc1</smiles>

Compound $1738(38)$
A diverse range of antibiotics, such as bleomycins, macrolides, polyethers, tetracyclines, have been studied for their polymerase-inhibiting properties using HIV-RT, AMV-RT and DNA polymerases as target enzymes. Many active compounds, e.g., further luzopeptins, suramin, sakyomycin A, have been identified, the majority of which were considered to be nonselective inhibitors of all of the enzymes. Exceptions to this, however, are the streptonigrin esters (47) $\left[\mathrm{R}=\mathrm{OCH}_{3}\right.$, $\mathrm{O}\left(\mathrm{CH}_{2}\right)_{2} \mathrm{CH}_{3}, \mathrm{OCH}\left(\mathrm{CH}_{3}\right)_{2}$, and $\mathrm{O}\left(\mathrm{CH}_{2}\right)_{3}\left(\mathrm{CH}_{3}\right]$, which inhibited HIV-1-RT selectively, albeit only with moderate potency (approx. $70 \%$ inhibition at $91-100 \mu \mathrm{M}$ ), and the free acid streptonigrin $(\mathrm{R}=\mathrm{OH})$, which inhibited both HIV-1-RT and AMV-RT (101). Another class of antibiotic compounds shown to inhibit HIV-1- and AMV-RT are the quinone antibiotics $\beta$ and $\gamma$-rubromycin $(\mathbf{4 8}, \mathbf{4 9})$. These compounds interact with the enzyme competitively at the template primer binding site, as shown through kinetic analysis. Both compounds inhibited HIV-1-RT with approximately the same potency, as evidenced by their respective $\mathrm{IC}_{50}$ values of $0.98 \mu \mathrm{M}$ (rubromycin $\beta$ ) and $0.62 \mu \mathrm{M}$ (rubromycin $\gamma$ ). The selectivity of both compounds towards HIV-1-RT as compared to DNA polymerase A is about 19- and 9-fold, respectively. Due to the cytotoxicity of the rubromycins cell-based HIV-1 infectivity studies clearly showed that there is no reduced viral infectivity at non-toxic concentrations. The compounds may, however, be useful as lead structures, especially regarding the quinone moiety, which seems to be a useful structural element when searching for agents active against RTs but not against cellular DNA polymerases (102). Novenamine analogues (50-52), synthetic derivatives of novobiocin, an antibiotic produced by Streptomyces niveus, contain the sugar noviose and diversely substituted coumarin residues. They all selectively inhibited the RNase $\mathrm{H}$ function of HIV-RT. Activity is dependent on the amphiphilic properties of the molecules, and only micelles of 50-52, formed at relatively high concentrations ( $\mathrm{IC}_{50}$ values in the range of 25 to $75 \mu \mathrm{M}$ ), inhibited the enzyme (103).<smiles>[2H][C@]12C(=O)OC[C@@H]1[C@H](c1ccc3c(c1)OCO3)Cc1cc3c(cc12)OCO3</smiles>

Lignan (39)
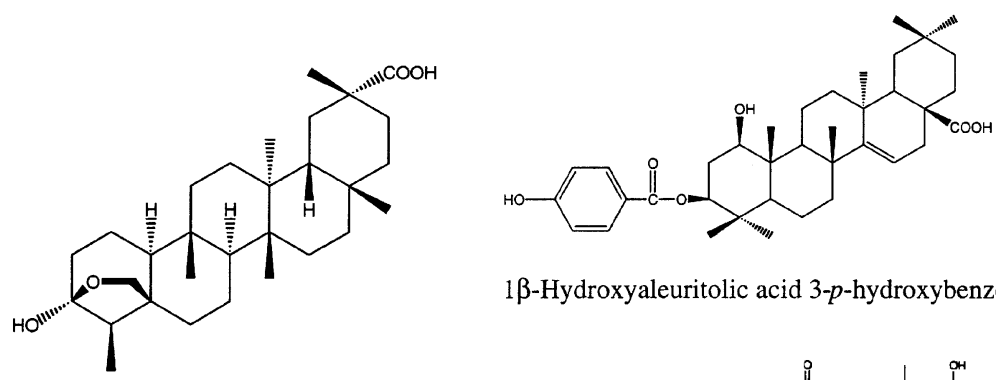

1 $\beta$-Hydroxyaleuritolic acid 3-p-hydroxybenzoate (41)

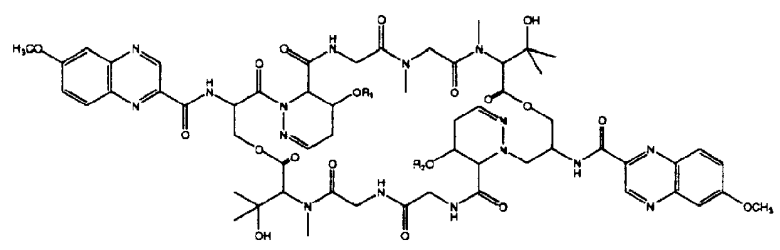

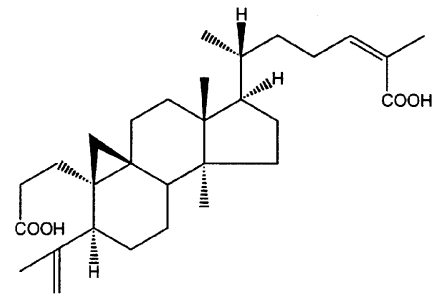

Nigranoic acid (42)
Salaspermic acid (40)

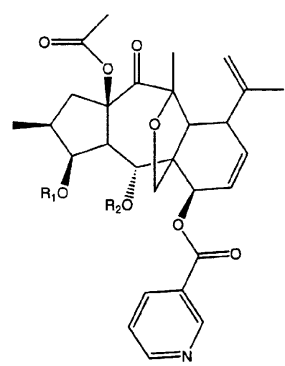

43: $\mathrm{R}_{1}=$ butanoyl

$R_{2}=$ propanoyl

44: $\mathrm{R}_{1}=\mathrm{R}_{2}=$ butanoyl
Quinoxapeptins A and B (45) / (46) 
In a large-scale screen of cyanobacterial (blue-green algal) extracts, more than 900 strains of cultivated cyanobacteria were investigated. Extracts of some of these algae, e.g., from Nostoc sp., Phormidium sp., Oscillatoria sp. were found to be active towards AMV-RT and HIV-1-RT, suggesting that this group of organisms may be a promising source of antiretroviral compounds (104). In another screening effort, the cyanobacterial metabolite ambigol A (53) from the extract of Fischerella ambigua was found to moderately inhibit HIV-1-RT $\left(\mathrm{IC}_{50}=54 \mu \mathrm{M}\right)(105,106)$. The antiviral effect of sulfoglycolipids from cyanobacteria was first detected in the cell-based $\mathrm{NCI}$ screening programme (107). Detailed investigation of sulfoglycolipids, which are known as structural elements of certain membranes, from several different cyanobacteria, e.g., from Scytonema sp., Oscillatoria trichoides and O.limnetica, showed potent HIV-1-RT inhibition (nearly $100 \%$ inhibition of the enzyme at $10 \mu \mathrm{M}$ ). This potent activity is dependent on the intact sulfoquinovopyranosyl glycerol (SQG) molecule which bears both the sulfonic acid and fatty acid residues as SQGs 54-57 (108, 109). The early studies at the NCI showed that this type of compound is able to inhibit the cytopathic effects of HIV on cultured cells. Accordingly in 1989, they were selected by the Decision Network Committee of the $\mathrm{NCI}$ for preclinical investigation. Since then, however, no encouraging news on their further development has been published, indicating that this group of natural products has no significance as antiviral agent.

The search for RT inhibitors by screening 545 cultivated Basidiomycetes led to the identification of structurally diverse fungal metabolites (110): podoscyphic acid (58), from a Tasmanian Podoscypha sp., displayed $\mathrm{IC}_{50}$ values of $35-70 \mu \mathrm{M}$ towards moloney murine leukemia virus (MMuLV) RT, $350 \mu \mathrm{M}$ towards AMV-RT, and HIV-1-RT was inhibited by $34 \%$ at $100 \mu \mathrm{g} / \mathrm{ml}$ (111). Clavicoronic acid (59) from Clavicorona pyxidata also inhibited MMuLV-RT and AMV-RT, but showed more potent activity with $\mathrm{IC}_{50}$ values of $19-38$ and $114-$ $133 \mu \mathrm{M}$, respectively; a $30 \%$ inhibition of HIV-1-RT was observed at $404 \mu \mathrm{M}$ (112). Several other compounds active against HIV-RT came from a Mniopetalum sp., which produced a series of new drimane-type sesquiterpenes, the mniopetals (60-65). Mniopetals A-F all exhibited weak antimicrobial and cytotoxic properties. Some of them also inhibited HIV-1-RT, with mniopetal $\mathrm{F}$ being the most active derivative $\left(\mathrm{IC}_{50}=\right.$ $30 \mu \mathrm{M})$. Interestingly, the different mniopetals (60-65) exhibited selectivity in their inhibitory properties when tested towards HIV-1-RT, AMV-RT and MMuLV-RT (113). Several pigments, which demonstrated antitumour activity, were isolated from Aspergillus terreus. One of them, asterriquinone (66), was selected for more detailed studies and several analogues were prepared (114). Investigations into the mechanism of the antitumour activity revealed the asterriquinones to strongly inhibit DNA polymerases. Thus, activity towards HIV-1-RT was evaluated, and asterriquinone and several of its analogues were found to inhibit HIV-1-RT with $\mathrm{IC}_{50}$ values in the 1 to $9 \mu \mathrm{M}$ range; the natural compound was the most selective but also the least active of all substances tested in this series (115).

\section{Reverse Transcriptase Inhibitors from Marine Organisms}

The search for RT inhibitors in animals has to date focussed largely on marine sponges. The first marine natural products found to inhibit HIV-RT were a group of quinone derivatives. A series of sesquiterpenoid hydroquinones and quinones, structurally related to the anti-HIV principle of the marine sponge Dysidea avara (Dysideidae), avarol (67) (116), was identified in several sponge species, and shown to inhibit<smiles>COc1ccc(-c2c(C)c(O)nc(-c3ccc4c(n3)C(=O)C(N)=C(O)C4=O)c2N)c(O)c1O</smiles>

Streptonigrins (47)

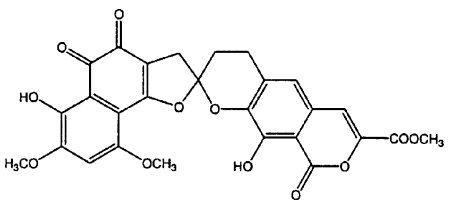

$\beta$-Rubromycin (48)

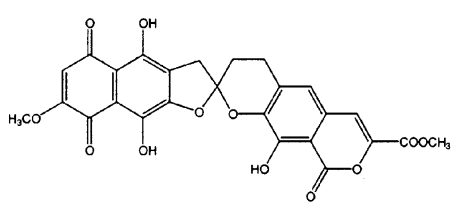

$\gamma$-Rubromycin (49)
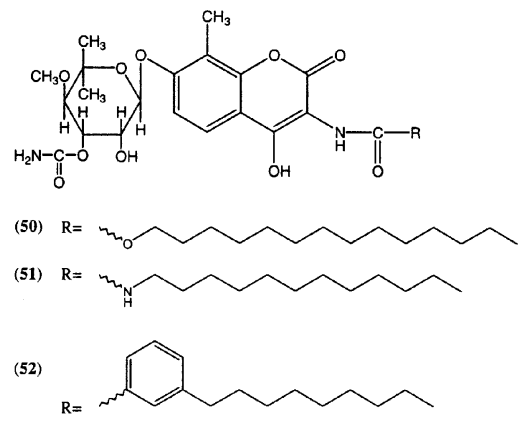

Novenamines (50-52)

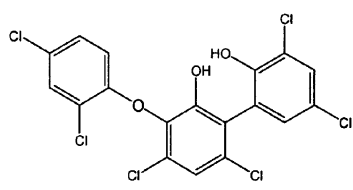

Ambigol A (53)

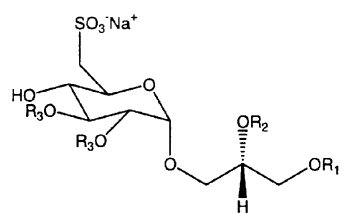

(54) $R_{1}=$ lineoyl, $R_{2}=$ palmitoyl, $R_{3}=$ palmitoyl

(55) $\mathrm{R}_{1}=$ lineoyl, $\mathrm{R}_{2}=$ palmitoyl, $\mathrm{R}_{3}=\mathrm{H}$

(56) $\mathrm{R}_{1}=$ palmitoyl, $\mathrm{R}_{2}=$ palmitoyl, $\mathrm{R}_{3}=\mathrm{H}$

(57) $R_{1}=$ oleoyl, $R_{2}=$ palmitoyl, $R_{3}=H$

Sulfoquinovopyranosyl glycerols (SQG) (54-57) 


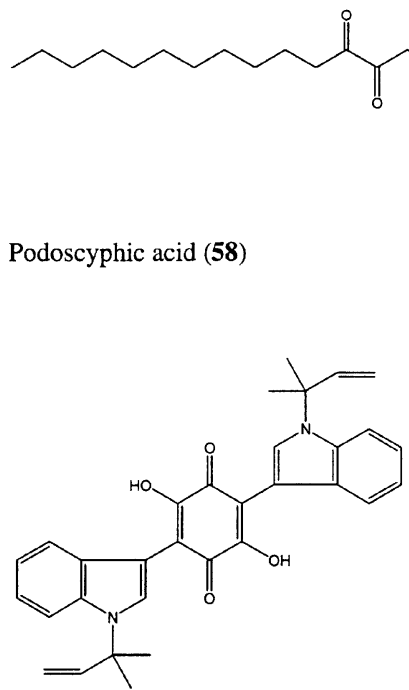

Asterriquinone (66)

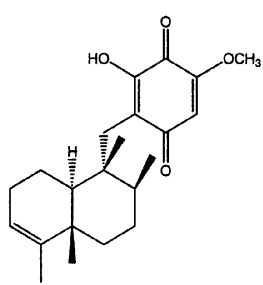

Avarone E (68)<smiles>CC1=C(C(=O)O)C(C(=O)O)=C[C@H]2CC(C)(C)C[C@H]12</smiles>

Clavicoronic acid (59)

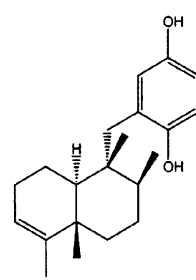

Avarol (67)

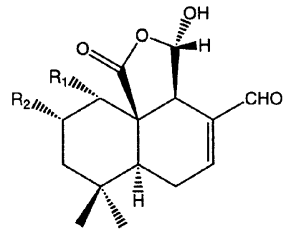

(60) $R_{1}=-\mathrm{OH}, \mathrm{R}_{2}=$

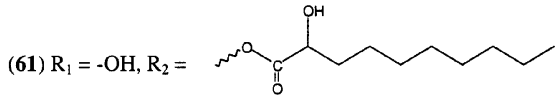<smiles>[R]O[R4]#[R]COC(=O)C(O)CCCCCC</smiles>

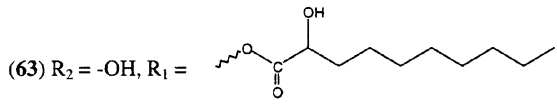

(64) $\mathrm{R}_{1}=\mathrm{R}_{2}=-\mathrm{OH}$

(65) $\mathrm{R}_{1}=-\mathrm{OH}, \mathrm{R}_{2}=-\mathrm{H}$

Mniopetals A - F (60-65)
HIV-1-RT. Avarone E (68) and avarol F (69) from D. cinerea were the most effective of the investigated compounds (117). They inhibited the RDDP activity of HIV-1-RT to $50 \%$ at 2.8 and $21 \mu \mathrm{M}$, respectively, and at concentrations of 140 and $147 \mu \mathrm{M}$, RNaseH activity was inhibited to more than $90 \%$. After investigation of all of the isolated derivatives the authors postulated that a hydroxyl group needed to be ortho to the hydroxyl/carbonyl group of the (hydro-)quinone ring for potent HIV-RT inhibitory activity. Thus, for avarol (67) and avarone no significant activities towards HIV-RT could be noticed (117). Several related compounds that met the abovementioned structural requirements were identified in $D$. cinerea (118), and in Smenospongia sp. (Irciniidae) (119). Illimaquinone (70), a Smenospongia sp. metabolite, potently inhibited the RNaseH activity of HIV-1-RT $\left(\mathrm{IC}_{50}=15 \mu \mathrm{M}\right)$ with a high degree of selectivity, having only little effect on cellular $\alpha$-DNA polymerase (119). In the course of a further investigation of marine organisms for HIV-RT inhibition another sponge-derived molecule with such a carbon-skeleton, hyatellaquinone (71), was isolated from Hyatella intestinalis (Spongiidae) (120). Other compounds with a structurally related carbon-skeleton but having a larger terpenoid moiety and being substituted with a sulfated aromatic ring belong to a series of hexaprenoid hydroquinones isolated from the marine sponge Toxiclona toxius (Demospongiae). Among them, toxiusol (72) was the most potent HIV-1-RT inhibitor $\left(\mathrm{IC}_{50}=1.5 \mu \mathrm{M}\right)$, which selectively and strongly inhibited the RDDP function of the enzyme (121). A structurally different class of RT inhibitory secondary metabolites from sponges are fatty acid derivatives bearing acetylene groups, a recent example being taurospongin A (73). This compound is composed of taurine linked via a hydroxylated and branched carboxylic acid to an unsaturated fatty acid residue. Compound $\mathbf{7 3}$ was isolated from the Okinawan sponge Hippospongia sp. (Spongiidae), and inhibited HIV-RT and DNA polymerase $\beta$ ( IC $_{50}=6.5$ and $7 \mu \mathrm{M}$, respectively) (122). Further acetylene-containing fatty acids, this time without sulfonic acid functions, were found to influence the polymerase activities of HIV-1-RT, such as petrosynol (74) and petrosolic acid (75) from Petrosia sp. (Petrosiidae), a Red Sea sponge. Petrosolic acid (75) inhibited the enzyme more potently, with $\mathrm{IC}_{50}$ values of 1.2 and $6.2 \mu \mathrm{M}$ with respect to RDDP and DDDP activity of HIV-1-RT, and the corresponding values for petrosynol (74) being 10- to 5-fold higher (123). Some spongederived alkaloids have also been identified as HIV-RT inhibitors. From a Red Sea Verongia sp. (Aplysinidae), 3,5,8trihydroxy-4-quinolone (76) has been isolated and its methyl ether derivative (77) prepared. Both alkaloids have potent HIV-1-RT inhibitory activity. The $\mathrm{IC}_{50}$ values for the HIV-1RDDP activity were determined to be $3 \mu \mathrm{M}$ (76) and $4 \mu \mathrm{M}(77)$, and for the DDDP activity $43 \mu \mathrm{M}$ and $34 \mu \mathrm{M}$, respectively (124).

The sponge Fascaplysinopis reticulata (Aplysinidae) from Fiji yielded three HIV-1-RT inhibitors, all with weak activities $\left(\mathrm{IC}_{50}>1 \mathrm{mg} / \mathrm{mL}\right)$ : isodehydroluffariellolide (78), fascaplysin (79), homofascaplysin A cation/dehydroluffariellolide diacid anion (80) (125). A further alkaloid, plakinidine A (81) from 


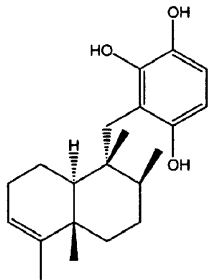

Avarol F (69)

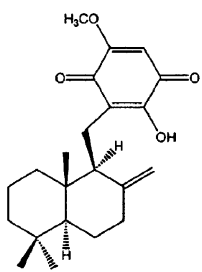

Hyatellaquinone (71)

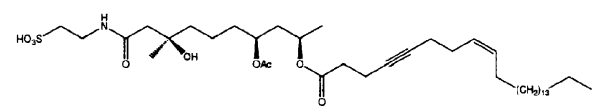

Taurospongin A (73)

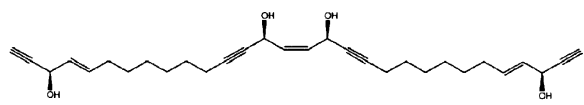

Petrosynol (74)

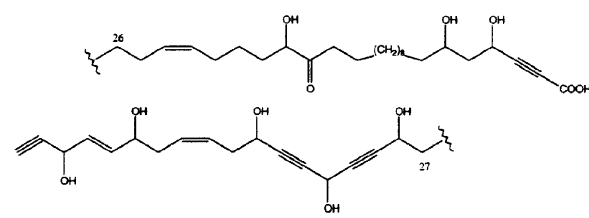

Petrosolic acid (75)<smiles>O=c1c(O)c[nH]c2c(O)ccc(O)c12</smiles>

3,5,8-Trihydroxy-4-quinolone (76)

Methyl ether derivative (77)

Plakortis sp. (Plakinidae), was found to inhibit HIV-1-RT weakly (at $1 \mathrm{mg} / \mathrm{ml}=3.3 \mathrm{mM}$ ) (126). The unusual carotenoid halocynthiaxanthin (82), also obtained from a Red Sea sponge, as yet unidentified, inhibits the RDDP function of HIV-1-RT and HIV-2-RT more potently ( $\mathrm{IC}_{50}=7 \mu \mathrm{M}$ and $\left.5 \mu \mathrm{M}\right)$ than the DDDP function $\left(\mathrm{IC}_{50}=28 \mu \mathrm{M}\right.$ and $\left.38 \mu \mathrm{M}\right)$. Halocyanthiaxan- thin is to date the only carotenoid with HIV-RT inhibitory activity (127).

Homologues of the antibacterial kelletinin I from the mollusc Kelletia kelletii (Prosobranchia) (128) were isolated from another hard-shelled snail, Buccinulum corneum (Buccinidae). Kelletinin A (83) was first identified as antiviral (and antimitotic), and then as an HIV-1-RT inhibitor (129), the potency and mechanism of action of which was investigated in detail. It was found to be a non-competitive inhibitor of the RDDP activity of diverse RTs, including HIV-1-RT. The inhibitory properties of kelletinin A ( IC $_{50} \approx 12 \mu \mathrm{M}$ ) were compared with less active structural analogues, and a mechanism of inhibition different from other NNRTIs was elucidated following kinetic analysis (130).

Algal extracts have been observed to have antiviral activities, e.g., (131), and more recently towards HIV in cell based assays (132). The latter study showed the aqueous extracts of the red algae Liagora boergeseni (Helminthocladiaceae), two Plocamium sp. (Plocamiaceae), Portieria hornemannii (Rhizophyllidaceae), Champia parvula, and of two brown algae of the genus Sargassum (Sargassaceae) to inhibit the replication of HIV (132). The aqueous extract of the red algae Schizymenia pacifica (Nemastomaceae) was found to inhibit the RTs of AMV and RLV (133). In the subsequent investigation of S. pacifica a carrageenan was purified that consisted of galactose $(73 \%), 3,6$-anhydrogalactose $(0.65 \%)$, and sulfonate $(20 \%)\left(\mathrm{M}_{\mathrm{r}} 2 \times 10^{6}\right)$. The purified carrageenan was shown to inhibit AMV-RT and HIV-1-RT, and HIV replication in vitro, with a comparable potency to that of other sulfated polysaccharides such as the heparins, other carrageenans, and dermatan sulfates (134). The mechanism of action of sulfated polysaccharides may thus not only be due to inhibition of virus cell adhesion (5), but also to inhibition of HIV-RT. The HIV-RT inhibitory principle in Peyssonnelia sp., (Peyssonneliaceae) proved to be peyssonol A (84), a brominated sesquiterpenoid hydroquinone similar to the sponge metabolites 67 72, but substituted with an aldehyde functionality (120). The biological activity of peyssonol A (84) has been neither quantified nor further described. Furthermore, an SQG molecule differing only in one fatty acid residue from the cyanobacterial metabolites 54-57 has been recently isolated from the marine red alga Gigartina tenella (Gigartinaceae) as inhibitor of HIV-1-RT $\left(\mathrm{IC}_{50}=11.2 \mu \mathrm{M}\right)$ and eukaryotic DNA polymerases (135). The diterpenoids dictyodial (85) and hydroxydictyodial (86) which have been isolated from brown algae of the genus Dictyota (Dictyotaceae), particularly D. dichotoma and D. patens, have been patented (136) as HIV-1-RT inhibitors and are characterised by their $\mathrm{IC}_{50}$ values of 9.2 and $4.3 \mu \mathrm{g} / \mathrm{ml}$ (30 and $13.5 \mu \mathrm{M}$ ), respectively. Interestingly, these algal metabolites also contain reactive aldehyde groups.

\section{Conclusions}

A large number of compounds have been investigated with respect to their possible use in the treatment of AIDS, specifically as HIV-1-RT inhibitors. Nevertheless, the discovery of further HIV-1-RT inhibitors is still accompanied with excitement, as it is always hoped that new and more potent compounds with novel mechanisms of inhibiting the enzyme will be found. To date, the screening of marine as well as terrestrial macro- and micro-organisms has resulted in the 
<smiles>CC(=CCCC1=CCOC1=O)CCC=C(C)CCC1=C(C)C(=O)CCC1(C)C</smiles>

Isodehydroluffariellolide (78)<smiles></smiles>

Fascaplysin (79)<smiles>CNc1c2c(c3nc4ccccc4c4c3c1N=C4)NCCC2=O</smiles>

Plakinidine A (81)

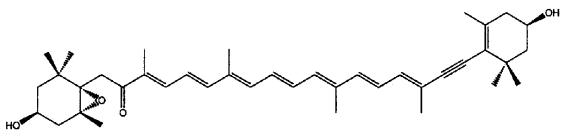

Halocynthiaxanthin (82)<smiles>CC1=C(CC/C(C)=C/CC/C(C)=C/CCC(=O)O)C(C)(C)CCC1</smiles><smiles></smiles>

Homofascaplysin A cation / Dehydroluffariellolide diacid anion (80)<smiles>OCC(O)C(O)C(O)CO</smiles><smiles>CC(=O)c1ccc(O)cc1</smiles>

Kelletinin A (83)

identification of a large number of natural products able to inhibit HIV-RT. As expected, many act either non-specifically, e.g., tannins and flavonoids, or they lack potency, or are too cytotoxic. The most promising RT inhibitory compounds of natural origin are probably those identified in the NCI screening programme: calanolide A (1) is a HIV-1-RT inhibitor with novel inhibitory properties when compared with the currently available NNRTIs and michelamine B (4) which inhibits HIV-RT in yet a different manner.

Higher plants are clearly the most extensively and sucessfully investigated natural source of potential HIV-1-RT inhibitors. Many problems, e.g., associated with the many unspecifically active and often ubiquitous "nuisance" compounds, which, as we are aware of now, have to be removed from extracts before embarking into screening and bioassay-guided isolation procedures, have been recognised and will allow further studies for HIV-1-RT inhibitors to be more efficient (137).

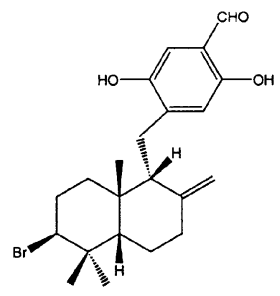

Peyssonol A (84)<smiles>CC(C)=CCC[C@]1(C)[C@@H](O)C/C(C)=C\C/C(O)=C/C[C@H]1O</smiles>

Hydroxydictyodial (86)

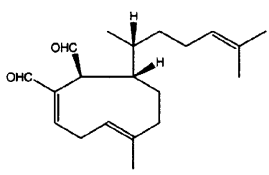

Dictyodial (85)
Marine samples on the other hand are a relatively poorly investigated source of HIV-RT inhibitors and thus represent a huge potential resource of lead structures. It also seems that compounds that have unspecific inhibitory properties are not so commonly encountered in these organisms, and are mainly sulphated low and high molecular weight substances.

\section{Acknowledgements}

We would like to thank Prof. Douglas Kinghorn, Department of Medicinal Chemistry and Pharmacognosy, College of Pharmacy, University of Illinois at Chicago, USA, and Prof. Sami Khalid, Department of Pharmacy, University of Khartoum, Sudan, for their valued comments concerning this review.

\section{References}

${ }^{1}$ De Clerq, E. (1995) in: Anti-AIDS Drug Development: Challenges, Strategies and Prospects, (Mohan, P., Baba, M., eds.), pp. 1-37, Harwood Academic Publishers, Chur, Switzerland.

2 Balzarini, J., Pelemans, H., Karlsson, A., DeClerq, E., Kleim, J.-P. (1996) Proc. Natl. Acad. Sci. USA 93, 13152 - 13157.

3 Lipsky, J. J. (1996) Lancet 348, 800-803.

${ }^{4}$ Tantillo, C., Ding, J., Jacobo-Molina, A., Nanni, R. G., Boyer, P. L., Hughes, S. H., Pauwels, R., Andries, K., Janssen, P. A. J., Arnold, E. (1994) J. Mol. Biol. 243, 369-387.

5 Vlietnick, A. J., De Bruyne, T., Apers, S., Pieters, L. A. (1998) Planta Med. 64, 97-109.

${ }^{6}$ Ng, T. B., Huang, B., Fong, W. P., Yeung, H. W. (1997) Life Sci. 61, 933-949.

${ }^{7}$ Kinghorn, D. A. (1995) in: Anti-AIDS Drug Development: Challenges, Strategies and Prospects, (Mohan, P., Baba, M., eds.), pp. 211 - 237, Harwood Academic Publishers, Chur, Switzerland.

${ }^{8}$ Baltimore, D. (1970) Nature 226, 1209-1211.

9 Temin, H. M., Mizutani, S. (1970) Nature 226, 1211 - 1213.

10 Huber, H. E., McCoy, J. M., Seehra, J. S., Richardsson, C. C. (1989) J. Biol. Chem. 264, 4669-4678. 
11 Barré-Sinoussi, F., Chermann, J. C., Rey, F., Nugeyre, M. T., Chamaret, S., Gruest, J., Dauguet, C., Axler-Blin, C., Vézinet-Brun, F., Rouzioux, C., Rozenbaum, W., Montagnier, L. (1983) Science $220,868-871$.

12 Rey, M. A., Spire, B., Dormont, D., Barré-Sinoussi, F., Montagnier, L., Chermann, J. C. (1984) Biochem. Biophys. Res. Comm. 121, $126-133$.

13 Rozenbaum, W., Dormont, D., Spire, B., Vilmer, E., Gentilini, M., Griscelli, C., Montagnier, L., Barré-Sinoussi, F., Cherman, J. C. (1985) Lancet I, 450-451.

14 Mitsuya, H., Weinhold, K. J., Furman, P. A., St. Clair, M. H., Nusinoff Lehrman, S., Gallo, R. C., Bolognesi, D., Barry, D. W., Broder, S. (1985) Proc. Natl. Acad. Sci. USA 82, 7096-7100.

15 Ostertag, W., Roessler, G., Krieg, C. J., Kind, J., Cole, T., Crozier, T., Gaedicke, G., Steinheider, G., Kluge, N., Dube, S. (1974) Proc. Nat. Acad. Sci. USA 71, 4980-4985.

${ }^{16}$ Farmerie, W. G., Loeb, D. D., Casavant, N. C., Huchinson III, C. A., Edgell, M. H., Swanstrom, R. (1987) Science 236, 305 - 308.

17 Müller, B., Restle, T., Weiss, S., Gautel, M., Sczakiel, G., Goody, R. S. (1989) J. Biol. Chem. 13975-13978.

18 Chattopadhyay, D., Evans, D. B., Deibel, Jr. M. R., Vosters, A. F., Eckenrode, F. M., Einspahr, H. M., Hui, J. O., Tomasselli, A. G., Zurcher-Neely, H. A., Heinrikson, R. L., Sharma, S. K. (1992) J. Biol. Chem. 267, 14227-14232.

19 Stahlhut, M. W., Olsen, D. B. (1996) in: Methods in Enzymology, Vol. 275, Viral Polymerases and Related Proteins, (Kuo, L. C., Olsen, D. B., Carrol, S. S., eds.), pp. 122 - 133, Academic Press, San Diego.

20 Kohlstaedt, L. A., Wang, J., Friedman, J. M., Rice, P. A., Steitz, T. A. (1992) Science 256, 1783-1790.

21 Jacobo-Molina, A., Ding, J., Nanni, R. G., Clark, Jr., A. D., Lu, X., Tantillo, C., Williams, R. L., Kamer, G., Ferris, A. L., Clark, P., Hizi, A., Hughes, S. H., Arnold, E. (1993) Proc. Natl. Acad. Sci. USA 90, 6320-6324.

22 Ogata, T., Higuchi, H., Mochida, S., Matsumoto, H., Kato, A., Endo, T., Kaji, A., Kaji, H. (1992) AIDS Res. Hum. Retroviruses 8, $1937-$ 1944.

${ }^{23}$ Moore, R. S., Pizza, C. (1992) Biochem. J. 288, 717 - 719.

24 Dormont, D., Spire, B., Barré-Sinoussi, F., Montagnier, L., Chermann, J. C. (1995) Ann. Inst. Pasteur/virol. 136 E, $78-83$.

25 Golomb, M., Grandgenett, D. P. (1979) J. Biol. Chem. 254, $1606-$ 1613.

${ }^{26}$ Cheng, Y., Dutschman, G. E., Bastow, K. F., Sarngadharan, M. G., Ting, R. Y. C. (1987) J. Biol. Chem. 262, 2187-2189.

27 Kutcha, R. D. (1996) in: Methods in Enzymology, Vol. 275, Viral Polymerases and Related Proteins, (Kuo, L. C., Olsen, D. B., Carrol, S. S., eds.), pp. 122 - 133, Academic Press, San Diego.

28 Eberle, J., Knopf, C. W. (1996) in: Methods in Enzymology, Vol. 275, Viral Polymerases and Related Proteins, (Kuo, L. C., Olsen, D. B., Carrol, S. S., eds.), pp. 122 - 133, Academic Press, San Diego.

29 Mizrahi, V., Benkovic, P., Benkovic, S. J. (1986) Proc. Natl. Acad. Sci. USA 83, 5769- 5773.

30 Kutcha, R. D., Benkovic, P., Benkovic, S. J. (1988) Biochemistry 27 $6716-6725$.

31 Eberle, J., Seibl, R. (1992) J. Virol. Methods 40, 347 - 356.

32 Ekstrand, D. H. L., Awad, R. J.-K., Källander, C. F. R., Gronowitz, J. S. (1996) Biotechnol. Appl. Biochem. 23, 95-105.

33 Tomita, N., Miyahara, M., Satoh, H., Suzuki, K., Kitajima, K., Miyamoto, K. (1995) Acta Med. Okayama 49, 69- 73.

34 Bergmann, W., Burke, D. C. (1995) J. Org. Chem. 21, 226- 228.

35 De Rudder, J., Privat de Garilhe, M. (1966) Antimicrob. Agents Chemother. 1965/1966, 578-584.

${ }^{36}$ Furman, P. A., Fyfe, J. A., St. Clair, M. H., Weinhold, K., Rideout, J. L., Freeman, G. A., Nusinoff Lehrman, S., Bolognese, D. P., Broder, S., Mitsuya, H., Barry, D. W. (1986) Proc. Natl. Acad. Sci. USA 83, $8333-8337$.
37 Merluzzi, V. J., Hargrave, K. D., Labadia, M., Grozinger, K., Skoog, M., Wu, J. C., Shih, C., Echner, K., Hattox, S., Adams, J., Rosehthal, A. S., Faanes, R., Eckner, R. J., Koup, R. A., Sullivan, J. L. (1990) Science $250,1411-1413$.

${ }^{38}$ Kashman, Y., Gustafson, K. R., Fuller, R. W., Cardellina II, J. H., McMahon, J. B., Currens, M. J., Buckheit, R. W., Hughes, S. H., Cragg, G. M., Boyd, M. R. (1992) J. Med. Chem. 35, 2735-2743.

39 Galinis, D. L., Fuller, R. W., McKee, T. C., Cardellina II, J. H., Gulakowski, R. J., McMahon, J. B., Boyd, M. R. (1996) J. Med. Chem. 39, 4507-4510.

40 Spence, R. A., Kati, W. M., Anderson, K. S., Johnson, K. A. (1995) Science 267, 988 - 993.

${ }^{41}$ Litvak, S. (1996) in: Retroviral Reverse Transcriptase, pp. 161 - 197, Springer Verlag, Heidelberg, Germany, and references cited therein.

42 Patil, A. D., Freyer, A. J., Eggleston, D. S., Haltiwanger, R. C., Bean, M. F., Taylor, P. B., Caranfa, M. J., Breen, A. L., Bartus, H. R., Johnson, R. K., Hertzberg, R. P., Westley, J. W. (1993) J. Med. Chem. 36, $4131-4138$.

43 McKee, T. C., Covington, C. D., Fuller, R. W., Bokesch, H. R., Young, S., Cardellina II, J. H., Kadushin, M. R., Soejarto, D. D., Stevens, P. F., Cragg, G. M., Boyd, M. R. (1998) J. Nat. Prod. 61, 1252-1256.

${ }^{44}$ Fuller, R. W., Bokesch, H. R., Gustafson, K. R., McKee, T. C., Cardellina II, J. H., McMahon, J. B., Cragg, G. M., Soejarto, D. D., Boyd, M. R. (1994) Bioorg. Med. Chem. Lett. 4,1961 - 1964.

45 Pengsuparp, T., Serit, M., Hughes, S. H., Soejarto, D. D., Pezzuto, J. M. (1996) J. Nat. Prod. 59, 839-842.

46 Cardellina II, J. H., Bokesch, H. R., McKee, T. C., Boyd, M. R. (1995) Bioorg. Med. Chem. Lett. 5, $1011-1014$.

47 Dharmaratne, H. R. W., Wanigasekera, W. M. A. P., Mata-Greenwood, E., Pezzuto, J. M. (1998) Planta Med. 64, 460- 461.

${ }^{48}$ Chenera, B., West, M. L., Finkelstein, J. A., Dreyer, G. B. (1993) J. Org. Chem. 58, 5605-5606.

49 Deshpande, P. P., Tagliaferri, F., Victory, S. F., Yan, S., Baker, D. C. (1995) J. Org. Chem. 60, 2964-2965.

50 Flavin, M. T., Rizzo, J. D., Khilevich, A., Kucherenko, A., Sheinkman, A., Vilaychak, V., Lin, L., Chen. W., Greenwood, E. M., Pengsuparp, T., Pezzuto, J. M., Hughes, S. H., Flavin, T. M., Cibulski, M., Boulanger, W. A., Shone, R. L., Xu, Z. (1996) J. Med. Chem. 39, $1303-1313$.

51 Boyd, M. R., Hallock, Y. F., Cardellina II, J. H., Manfredi, K. P., Blunt, J. W., McMahon, J. B., Buckheit, Jr., R. W., Bringman, G., Schäffer, M., Cragg, G. M., Thomas, D. W., Jato, J. G. (1994) J. Med. Chem. 37, $1740-1745$.

52 McMahon, J. B. Currens, M. J., Gulakowski, R. J., Buckheit, Jr., R. W., Lackman-Smith, C., Hallock, Y. F., Boyd, M. R. (1995) Antimicrob. Agents Chemother. 39, 484-488.

53 Schinazi, R. F., Chu, C. K., Babu, J. R., Oswald, B. J., Saalmann, V., Cannon, D. L., Eriksson, B. F. H., Nasr, M. (1990) Antiviral Res. 13, $265-272$

54 Higuchi, H., Mori, K., Kato, A., Ohkuma, T., Endo, T., Kaji, H., Kaji, A. (1991) Antiviral Res. 15, 205-216.

55 Anker, L., Gopalakrishna, R., Jones, K. D., Law, R. E., Couldwell, W. T. (1995) Drugs Fut. 20, 511 -517, and references cited therein.

56 Meruelo, D., Lavie, G., Lavie, D. (1988) Proc. Natl. Acad. Sci. USA $85,5230-5234$.

57 Lavie, G., Valentine, F., Levin, B., Mazur, Y., Gallo, G., Lavie, D., Weiner, D., Meruelo, D. (1989) Proc. Natl. Acad. Sci. USA 86, 5963 - 5967.

58 Lenard, J., Rabson, A., Vanderoef, R. (1993) Proc. Natl. Acad. Sci. USA 90, 158-162.

59 VIMRx Elaborates on Clinical Trial Results for AIDS, VIMRx Pharmaceuticals, Inc., Press Release 1996, September 19.

60 Pengsuparp, T., Cai, L., Constant, H., Fong, H. H. S., Lin, L., Kinghorn, A. D., Pezzuto, J. M., Cordell, G. A., Ingolfsdottir, K., Wagner, H., Hughes, S. H. (1995) J. Nat. Prod. 58, 1024-1031. 
61 Kakiuchi, N., Hattori, M., Namba, T., Nishizawa, M., Yamagishi, T., Okuda, T. (1985) J. Nat. Prod. 48, 614-621.

62 Spedding, G., Ratty, A., Middleton, J., A. (1989) Antiviral Res. 12, 99- 110 .

63 Ono, K., Nakane, H., Fukushima, M., Chermann, J., Barré-Sinoussi, F. (1990) Eur. J. Biochem. 190, 469-476.

64 Kusumoto, I. T., Hattori, M., Miyaichi, Y., Tomimori, T., Hanaoka, M., Namba, T. (1991) Shoyakugaku Zasshi, 45, 240-254.

65 Ono, K., Nakane, H., Zeng-Mu, M., Ose, Y., Sakai, Y., Mizuno, M. (1989) Chem. Pharm. Bull. 37, 1810-1812.

66 Okuda, T., Yoshida, T., Hatano, T. (1989) Planta Med. 55, 117-122.

67 Nakane, H., Fukushima, M., Ono, K. (1990) J. Nat. Prod. 53, $1234-$ 1240.

68 Nishizawa, M., Yamagishi, T., Dutschman, G. E., Parker, W. B., Bodner, A. J., Kilkuskie, R. E., Cheng, Y., Lee, K.-H. (1989) J. Nat. Prod. 52, $762-768$.

69 Yoshida, T., Ito, H., Hatano, T., Kurata, M., Nakanishi, T., Inada, A., Murata, H., Inatomi, Y., Matsuura, N., Ono, K., Nakane, H., Noda, M., Lang, F. A., Murata, J. (1996) Chem. Pharm. Bull. 44, 14361439.

70 El-Mekkawy, S., Meselhy, M. R., Kusumoto, I. T., Kadota, S., Hattori, M., Namba, T. (1995) Chem. Pharm. Bull. 43, 641 - 648.

71 Saijo, R., Nonaka, G., Nishioka, I. (1989) Chem. Pharm. Bull. 37, 2624-2630.

72 Nonaka, G., Nishioka, I., Nishizawa, M., Yamagishi, T., Kashiwada, Y., Dutschman, G. E., Parker, W. B., Bodner, A. J., Kilkuskie, R. E., Cheng, Y., Lee, K.-H. (1990) J. Nat. Prod. 53, 587-595.

73 Kilkuskie, R. E., Kashiwada, Y., Nonaka, G., Nishioka, I., Bodner, A. J., Cheng, Y., Lee, K.-H. (1992) Bioorg. Med. Chem. Lett. 2, 15291534.

74 Musci, I., Prágai, B. M. (1985) Experientia 41, 930-931.

75 Wang, J., Hou, C., Liu, Y., Lin, L., Gil, R. R., Cordell, G. A. (1994) J. Nat. Prod. 57, 211 - 217.

76 Shigematsu, N., Kouno, I., Kawano, N. (1983) Phytochemistry 22, $323-325$.

77 Arisawa, M., Fujita, A., Suzuki, R., Hayashi, T., Morita, N., Kawano, N., Koshimura, S. (1985) J. Nat. Prod. 48, 455-459.

78 Nakane, H., Arisawa, M., Fujita, A., Koshimura, S., Ono, K. (1991) FEBS Lett. 286, 83-85.

79 Sethi, V. S., Sethi, M. L. (1975) Biochem. Biophys. Res. Commun. 63, 1070- 1076.

80 Sethi, M. (1979) J. Nat. Prod. 42, 187-196.

81 Sethi, M. (1983) J. Pharm. Sci. 72, 538-541.

82 Tan, G. T., Miller, J. F., Kinghorn, A. D., Hughes, S. H., Pezzuto, J. M. (1992) Biochem. Biophys. Res. Commun. 185, 370-378.

83 Tan, G. T., Kinghorn, A. D., Hughes, S. H., Pezzuto, J. M. (1991) J. Biol. Chem. 266, 23529-23536.

84 Tan, G. T., Pezzuto, J. M., Kinghorn, A. D., Hughes, S. H. (1991) J. Natl. Prod. 54, $143-154$.

85 McCormick, J. L., McKee, T. C., Cardellina II, J. H., Boyd, M. R. (1996) J. Nat. Prod. 59, 469-471.

86 MacRae, W. D., Hudson, J. B., Towers, G. H. N. (1989) Planta Med. $55,531-535$.

87 Charlton, J. L. (1998) J. Natl. Prod. 61, 1447-1451.

88 Schröder, H. C., Merz, H., Steffen, R., Müller, W. E. G., Sarin, P. S., Trumm, S., Schulz, J., Eich, E. (1990) Z. Naturforsch. 45c, 12151221.

89 Pfeifer, K., Merz, H., Steffen, R., Müller, W. E. G., Trumm, S., Schulz, J., Eich, E., Schröder, H. C. (1992) J. Pharm. Med. 2, 75-97.

90 Eich, E., Pertz, H., Kaloga, M., Schulz, J., Fesen, M. R., Mazumder, A., Pommier, Y. (1996) J. Med. Chem. 39, 86 - 95.

91 Fujihashi, T., Hara, H., Sakata, T., Mori, K., Higuchi, H., Tanaka, A., Kaji, H., Kaji, A. (1995) Antimicrob. Agents Chemother. 39, 20002007.

92 Hara, H., Fujihashi, T., Sakata, T., Kaji, A., Kaji, H. (1997) AIDS Res. Hum. Retroviruses 13, 695-705.

93 Ulubelen, A., Gil, R. R., Cordell, G. A., Meriçli, A. H., Meriçli, F. (1995) Phytochemistry 39, 417-422.
${ }^{94}$ Chen, K., Shi, Q., Kashiwada, Y., Zhang, D., Hu, C., Jin, J., Nozaki, H., Kilkuskie, R. E., Tramontano, E., Cheng, Y., McPhail, D. R., McPhail, A. T., Lee, K.-H. (1992) J. Nat. Prod. 55, 340-346.

95 Chaudhuri, S. K., Fullas, F., Brown, D. M., Wani, M. C., Wall, M. E., Cai, L., Mar, W., Lee, S. K., Luo, Y., Zaw, K., Fong, H. H. S., Pezzuto, J. M., Kinghorn, A. D. (1995) J. Nat. Prod. 58, 1-9.

96 Pengsuparp, T., Cai, L., Fong, H. H. S., Kinghorn, A. D., Pezzuto, J. M., Wani, M. C., Wall, M. E. (1994) J. Nat. Prod. 57, 415-418.

97 Sun, H., Qiu, S., Lin, L., Wang, Z., Lin, Z., Pengsuparp, T., Pezzuto, J. M., Fong, H. H. S., Cordell, G. A., Farnsworth, N. R. (1996) J. Nat. Prod. 59, 525-527.

98 Öksüz, S., Gürek, F., Gil, R. R., Pengsuparp, T., Pezzuto, J. M., Cordell, G. A. (1995) Phytochemistry 38, 1457-1462.

99 Lingham, R. B., Hsu, A. H. M., O'Brien, J. A., Sigmund, J. M., Sanchez, M., Gagliardi, M. M., Heimbuch, B. K., Genilloud, O., Maring, I., Diez, M. T., Hirsch, C. F., Zink, D. L., Liesch, J. M., Koch, G. E., Gartner, S. E., Garrity, G. M., Tsou, N. N., Salituro, G. M. (1996) J. Antibiotics 49, $253-259$.

100 Ohkuma, H., Sakai, F., Nishiyama, Y., Ohbayashi, M., Imanishi, H., Konishi, M., Miyake, T., Koshiyama, H., Kawaguchi, H. (1980) J. Antibiotics 33, 1087-1097.

101 Take, Y., Inouye, Y., Nakamura, S., Allaudeen, H. S., Kubo, A. (1989) J. Antibiotics 42, 107-115.

102 Goldman, M. E., Salituro, G. S., Bowen, J. A., Williamson, J. M., Zink, D. L., Schleif, W. A., Emini, E. A. (1990) Mol. Pharmacol. 38, 20-25.

103 Althaus, I. W., Franks, K. M., Langley, K. B., Kezdy, F. J., Peterson, T., Buxser, S. E., Decker, D. E., Dolak, L. A., Ulrich, R. G., Reusser, F. (1996) Experientia 52, 329-335.

104 Lau, A. F., Siedlecki, J., Anleitner, J., Patterson, G. M. L., Caplan, F. R., Moore, R. E. (1993) Planta Med. 59, 148-151.

105 Falch, B. S., König, G. M., Wright, A. D., Sticher, O., Angerhofer, C. K., Pezzuto, J. M., Bachmann, H. (1995) Planta Med. 61, 321 - 328.

106 Falch, B. S., König, G. M., Wright, A. D., Sticher, O., Rüegger, H., Bernardinelli, G. (1993) J. Org. Chem. 58, 6570-6575.

107 Gustafson, K. R., Cardellina II, J. H., Fuller, R. W., Weislow, O. S., Kiser, R. F., Snader, K. M., Patterson, G. M. L., Boyd, M. R. (1989) J. Nat. Cancer Inst. 81, 1254-1258.

108 Reshef, V., Mizrachi, E., Maretzki, T., Silberstein, C., Loya, S., Hizi, A., Carmeli, S. (1997) J. Nat. Prod. 60, 1251 - 1260.

109 Loya, S., Reshef, V., Mizrachi, E., Silberstein, C., Rachamin, Y., Carmeli, S., Hizi, A. (1998) J. Nat. Prod. 61, 891 - 895.

110 Anke, T., Erkel, G., Kocksch, G., Kuschel, A., Gimenez, A., Velten, R., Steglich, W. (1993) in: Wege zu neuen Produkten und Verfahren der Biotechnologie, (Anke, T., Onken, U., eds.), pp. 15-25, VCH Verlagsgesellschaft, Weinheim.

111 Erkel, G., Anke, T., Velten, R., Steglich, W. (1991) Z. Naturforsch. $46 c, 442-450$.

112 Erkel, G., Anke, T., Gimenez, A., Steglich, W. (1992) J. Antibiotics 45, 29-37.

113 Kuschel, A., Anke, T., Velten, R., Klostermeyer, D., Steglich, W., König, B. (1994) J. Antibiotics 47, 733-739.

114 Arai, K., Masuda, K., Kiriyama, N., Nitta, K., Yamamoto, Y., Shimizu, S. (1981) Chem. Pharm. Bull. 29, 961 - 969.

115 Ono, K., Nakane, H., Shimizu, S., Koshimura, S. (1991) Biochem. Biophys. Res. Commun. 174, 56-62.

116 Sarin, P. S., Sun, D., Thornton, A., Müller, W. E. G. (1987) J. Natl. Cancer Ins. 78, 663-666.

117 Loya, S., Hizi, A. (1990) FEBS Lett. 269, 131 - 134.

118 Hirsch, S., Rudi, A., Kashman, Y., Loya, Y. (1991) J. Nat. Prod. 54, $92-97$.

119 Loya, S., Tal, R., Kashman, Y., Hizi, A. (1990) Antimicrob. Agents Chemother. 34, 2009-2012.

120 Talpir, R., Rudi, A., Kashman, Y., Loya, Y., Hizi, A. (1994) Tetrahedron 50, 4179-4184.

121 Loya, S., Tal, R., Hizi, A., Issacs, S., Kashman, Y., Loya, Y. (1993) J. Nat. Prod. 56, 2120- 2125. 
122 Ishiyama, H., Ishibashi, M., Ogawa, A., Yoshida, S., Kobayashi, J. (1997) J. Org. Chem. 62, 3831-3836.

123 Isaacs, S., Kashman, Y., Loya, S., Hizi, A., Loya, Y. (1993) Tetrahedron 49, 10435 - 10438.

124 Loya, S., Rudi, A., Tal, R., Kashman, Y., Loya, Y., Hizi, A. (1994) Arch. Biochem. Biophys. 309, 315-322.

125 Jimenez, C., Quinoa, E., Adamczeski, M., Hunter, L. M., Crews, P. (1991) J. Org. Chem. 56, 3403 - 3410.

126 Inman, W. D., ONeill-Johnson, M., Crews, P. (1990) J. Am. Chem. Soc. $112,1-4$.

127 Loya, S., Kashman, Y., Hizi, A. (1992) Arch. Biochem. Biophys. 293, 208-212.

128 Tymiak, A. A., Rinehart, Jr., K. L. (1983) J. Am. Chem. Soc. 105, $7396-7401$

129 Silvestri, I., Albonici, L., Ciotti, M., Lombardi, M. P., Sinibaldi, P., Manzanri, V., Orlando, P., Carretta, F., Strazzullo, G, Grippo, P. (1995) Experientia 51, 1076 - 1080.

130 Orlando, P., Strazzullo, G., Carretta, F., De Falco, M., Grippo, P. (1996) Experientia 52, 812-817.

131 Richards, J. T., Kern, E. R., Glasgow, L. A., Overall, Jr., J. C., Deign, E. F., Hatch, M. T. (1978) Antimicrob. Agents Chemother. 14, 24-30.

132 Hayashi, K., Hamad, J., Hayashi, T. (1996) Phytother. Res. 10, $233-237$.

133 Nakashima, H., Kido, Y., Kobayashi, N., Motoki, Y., Neushul, M., Yamamoto, N. (1987) J. Cancer Res. Clin. Oncol. 113, 413 - 416.

134 Nakashima, H., Kido, Y., Kobayashi, N., Motoki, Y., Neushul, M., Yamamoto, N. (1987) Antimicrob. Agents Chemother. 31, 15241528.

135 Ohta, K., Mizushina, Y., Hirata, N., Takemura, M., Sugawara, F., Matsukage, A., Yoshida, S, Sakaguchi, K. (1998) Chem. Pharm. Bull. 46, 684-686.

136 Ninomiya, M., Matsuie, S., Kawakubo, A., Mifji, N. (1994) Japanese Patent JP 75839, Apr. 14. 94.

137 Cardellini II, J. H., Munro, M. H. G., Fuller, R. W., Manfredi, K. P., McKee, T. C., Tischler, M., Bokesch, H. R., Gustafson, K. R., Beutler, J. A., Boyd, M. R. (1993) J. Nat. Prod. 56, 1123-1129.

\section{Prof. Dr. G. M. König}

Institute for Pharmaceutical Biology University of Bonn

Nußallee 6

D-53115 Bonn

\section{Germany}

E-mail: g.koenig@uni-bonn.de

Fax: + 49228733250 